\title{
Physico-Chemical Studies on the Coordination Compounds of Thiazolidin-4-One
}

\author{
Dinesh Kumar, ${ }^{1}$ Amit Kumar, ${ }^{2}$ and Jyoti Sharma ${ }^{3}$ \\ ${ }^{1}$ Department of Chemistry, National Institute of Technology, Haryana, Kurukshetra 136119, India \\ ${ }^{2}$ Department of Chemistry, Haryana College of Technology \& Management, Haryana, Kaithal 136027, India \\ ${ }^{3}$ Department of Chemistry, International Institute of Engineering and Technology, Haryana, Kurukshetra 136118, India
}

Correspondence should be addressed to Amit Kumar; amit_vashistha2004@yahoo.co.in

Received 13 March 2012; Revised 1 August 2012; Accepted 15 August 2012

Academic Editor: Patricia Valentao

Copyright (c) 2013 Dinesh Kumar et al. This is an open access article distributed under the Creative Commons Attribution License, which permits unrestricted use, distribution, and reproduction in any medium, provided the original work is properly cited.

A dry benzene solution of the Schiff base, $N$-(2-hydroxyphenyl)- $3^{\prime}$-carboxy-2' -hydroxybenzylideneimine upon reacting with mercaptoacetic acid undergoes cyclization and forms $N$-(2-hydroxyphenyl)-C-( $3^{\prime}$-carboxy- $2^{\prime}$-hydroxyphenyl)thiazolidin-4-one, $\mathrm{LH}_{3}$ (I). A MeOH solution of $\mathrm{I}$ reacts with $\mathrm{Mn}^{\mathrm{II}}, \mathrm{Cu}^{\mathrm{II}}, \mathrm{Zn}^{\mathrm{II}}, \mathrm{Fe}^{\mathrm{III}}$ and $\mathrm{MoO}_{2}^{\mathrm{VI}}$ ions and forms the monomeric coordination compounds, $\left[\mathrm{Mn}(\mathrm{LH})(\mathrm{MeOH})_{3}\right](\mathbf{I I}),[\mathrm{Cu}(\mathrm{LH})(\mathrm{MeOH})](\mathbf{I I I}),[\mathrm{Zn}(\mathrm{LH})(\mathrm{MeOH})](\mathbf{I V}),\left[\mathrm{FeCl}(\mathrm{LH})(\mathrm{MeOH})_{2}\right](\mathbf{V})$, and $\left[\mathrm{MoO}_{2}(\mathrm{LH})(\mathrm{MeOH})\right](\mathrm{VI})$. The coordination compounds have been characterized on the basis of elemental analyses, molar conductance, molecular weight, spectral (IR, reflectance, ESR) studies, and magnetic susceptibility measurements. I behaves as a dibasic tridentate OOS donor ligand in these compounds. The compounds are nonelectrolytes $\left(\Lambda_{\mathrm{M}}=6.2-13.8 \mathrm{mho} \mathrm{cm}^{2} \mathrm{~mol}^{-1}\right)$ in DMF. A square-planar structure for III; a tetrahedral structure for IV and an octahedral structure for II, V, and VI are suggested.

\section{Introduction}

Heterocyclic compounds of Schiff bases possessing thiazolidin-4-one skeleton (having carbonyl group at 4th position) are known for their versatile pharmacological and industrial importance [1]. They have been studied extensively because of their ready accessibility, diversed chemical reactivity, and broad spectrum of biological activities [2].

In recent years, thiazolidin-4-ones have been investigated most extensively. The presence of a thiazolidine ring in penicillin and related derivatives was the first recognition of its occurrence in nature [3]. Thiazolidine-4-one represents a prevalent scaffold in drug discovery [4]. Literature surveys show that thiazolidine-4-ones have many interesting activity profiles, namely COX-1 inhibitors [5], inhibitors of the bacterial enzyme MurB, which was a precursor acting during the biosynthesis of peptidoglycan [6], nonnucleoside inhibitors of HIV-RT [7] and antihistaminic agents [8]. Thiazolidinones are also known to exhibit antibacterial, anticonvulsant, antifungal, amoebicidal, antioxidant, and anticancer [9-12] activities.

A perusal of the literature reveals that much has been reported on the syntheses and characterization $[13,14]$ of a variety of thiazolidin-4-ones, but little is known about their coordination compounds [15-17].

Metal ions play a key role in the actions of drugs. They are involved in specific interactions with antibiotics, proteins, membrane components, nucleic acids, and other biomolecules $[18,19]$. Many drugs possess modified pharmacological properties in the form of the metal complexes. Transition metal ions possess an important role in the design of metal-based drugs and such complexes are more effective against infectious diseases compared to the uncomplexed drugs $[20,21]$. Metals complexes of $\mathrm{Cu}(\mathrm{II})$ has proved to be beneficial in diseases such as tuberculosis, gastric ulcers, 
rheumatoid arthritis, and cancers [22]. The complexes of $\mathrm{Fe}(\mathrm{III})$ and $\mathrm{Mn}$ (II) also have excellent medicinal values [23].

Hence these facts prompted us to explore the coordination behavior of a newly synthesized thiazolidin-4-one with transition metal ions.

In this paper, we describe the syntheses and characterization of $N$-(2-hydroxyphenyl)-C-( $3^{\prime}$-carboxy- $2^{\prime}$ hydroxyphenyl) thiazolidin-4-one, $\mathrm{LH}_{3}$ (I) and its coordination compounds with $\mathrm{Mn}^{\mathrm{II}}, \mathrm{Cu}^{\mathrm{II}}, \mathrm{Zn}^{\mathrm{II}}, \mathrm{Fe}^{\mathrm{III}}$, and $\mathrm{MoO}_{2}{ }^{\mathrm{VI}}$ ions. The structure of Schiff base and thiazolidin-4-one, LH3 (I) is shown in Figure 1.

\section{Experimental}

2.1. Materials. 2-Aminophenol [Loba-Chemie (Mumbai)], mercaptoacetic acid, dry benzene, sodium bicarbonate, ammonium molybdate(VI) tetrahydrate, acetyl acetone [Ranbaxy], manganese(II) acetate tetrahydrate, iron(III) chloride (anhydrous) [Sarabhai], copper(II) acetate monohydrate, and zinc(II) acetate dihydrate [s d fine-chem Limited] were used as received for the syntheses. 3Aldehydo-2-hydroxybenzoic acid and bis(acetylacetonato) dioxomolybdenum(VI) were synthesized by following the reported procedure [24].

2.2. Analyses and Physical Measurements. The organic skeleton of the respective coordination compounds was decomposed by the slow heating of $\sim 0.1 \mathrm{~g}$ of the latter, with conc. $\mathrm{HNO}_{3}$. The residue was dissolved in minimum amount of conc. $\mathrm{HCl}$ and the corresponding metal ions were estimated as follows: the $\mathrm{Mn}$ (II) and $\mathrm{Zn}$ (II) contents of the respective coordination compounds were estimated by complexometric titration method against standardized EDTA solution using eriochrome black- $\mathrm{T}$ as the indicator. The $\mathrm{Cu}(\mathrm{II})$ contents was estimated iodometrically against a standard solution of sodium thiosulphate to the starch end point. The $\mathrm{Fe}(\mathrm{III})$ ions were reduced to $\mathrm{Fe}(\mathrm{II})$ ions with aqueous $\mathrm{SnCl}_{2}$ and then estimated against standard $\mathrm{K}_{2} \mathrm{Cr}_{2} \mathrm{O}_{7}$ solution using $\mathrm{N}$-phenylanthranilic acid as an indicator. The molybdenum contents was estimated gravimetrically after decomposing the given $\mathrm{MoO}_{2}(\mathrm{VI})$ compound with a few drops of conc. $\mathrm{HNO}_{3}$ and conc. $\mathrm{H}_{2} \mathrm{SO}_{4}$, and then igniting the residue in an electric Bunsen at $500^{\circ} \mathrm{C} . \mathrm{MoO}_{3}$ obtained was dissolved in $6 \mathrm{~N} \mathrm{NaOH}$, and then molybdenum was estimated as bis $(8-$ hydroxyquinolinato) dioxomolybdenum(VI).

The $\mathrm{C}, \mathrm{H}$, and $\mathrm{N}$ contents of $\mathbf{I}$ and its coordination compounds were determined by CHN Eager analyzer model300. The $\mathrm{S}$ and $\mathrm{Cl}$ contents of $\mathbf{I}$ and its coordination compounds were estimated gravimetrically as $\mathrm{BaSO}_{4}$ and $\mathrm{AgCl}$, respectively. The molecular weight measurements were carried out by the Rast method using diphenyl as the solvent [25].

The molar conductances $\left(\Lambda_{M}\right)$ of the coordination compounds were measured in DMF with the help of a Toshniwal conductivity bridge (CL01-02A) and a dip-type cell calibrated with $\mathrm{KCl}$ solutions. The IR spectra were recorded in $\mathrm{KBr}$ pellets $\left(4000-400 \mathrm{~cm}^{-1}\right)$ on a Beckman-20 spectrophotometer. The reflectance spectra were recorded on a Beckmann DU

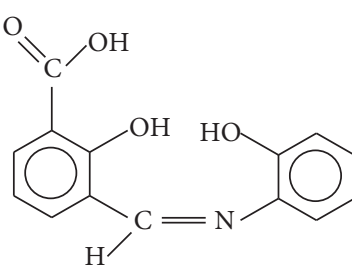

[Schiff base]

(a)

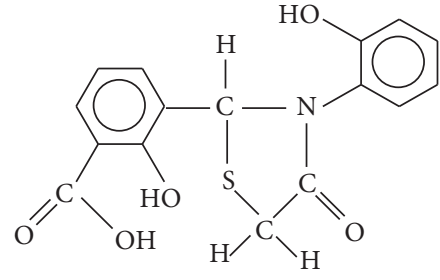

[I] (b)

FIGURE 1

spectrophotometer attached with a reflectance arrangement. The magnetic susceptibility measurements were carried out at room temperature, using $\mathrm{Hg}\left[\mathrm{Co}(\mathrm{NCS})_{4}\right]$ as the standard [26]. The diamagnetic corrections were computed using Pascal's constants. The magnetic susceptibilities were corrected for temperature independent paramagnetism term (TIP) [26] using value of $60 \times 10^{-6} \mathrm{cgs}$ units for $\mathrm{Cu}(\mathrm{II})$ ions, zero for $\mathrm{Mn}(\mathrm{II})$, and $\mathrm{Fe}(\mathrm{III})$ ions.

The ESR spectrum of III was recorded at liquid $\mathrm{N}_{2}$ temperature in polycrystalline solids on a Varian V4502-12 $\mathrm{X}$-band ESR spectrophotometer with $100 \mathrm{KHz}$ modulation using diphenylpicrylhydrazide as a $g$-marker and monitoring the frequency with frequency meter.

2.3. Synthesis of the Schiff Base. The Schiff base was prepared as per the reported procedure [27].

2.4. Synthesis of I. A dry benzene solution of the Schiff base $(2.57 \mathrm{~g}, 10 \mathrm{mmol})$ and mercaptoacetic acid $(0.92 \mathrm{~g}$, $10 \mathrm{mmol}$ ) were refluxed for $12 \mathrm{~h}$ on a water bath. The mixture was cooled to room temperature and then was washed with $10 \%$ sodium bicarbonate solution. The benzene layer was separated using a separating funnel. The partial evaporation of the benzene layer gave a solid product, which was filtered, washed with, and recrystallized from petroleum ether. Yield $=25 \%$. Anal: $\left(\mathrm{I}, \mathrm{C}_{16} \mathrm{H}_{13} \mathrm{NO}_{5} \mathrm{~S}\right)$ (obsd: C, $57.80 \% ; \mathrm{H}, 3.75 \%$; N $4.10 \%$; S, 9.50\%. calc.: C, $58.01 \% ; \mathrm{H}, 3.93 \% ; \mathrm{N}, 4.23 \%$; S, 9.67\%); IR bands (KBr): $2860 \mathrm{~cm}^{-1}[v(\mathrm{O}-\mathrm{H})$ (intramolecular H-bonding)], $1700 \mathrm{~cm}^{-1} \quad[v(\mathrm{C}=\mathrm{O})$ (thiazolidinone ring) $], \quad 1670 \mathrm{~cm}^{-1}$ $\left[v(\mathrm{C}=\mathrm{O})(\right.$ carboxylic) $], \quad 1575 \mathrm{~cm}^{-1}[v(\mathrm{C}-\mathrm{N})$ (thiazolidinone ring) $], \quad 1525 \mathrm{~cm}^{-1} \quad[v(\mathrm{C}-\mathrm{O})$ (phenolic) $]$, and $835 \mathrm{~cm}^{-1}$ $[v(\mathrm{C}-\mathrm{S})$ (thiazolidinone ring)].

2.5. Syntheses of Coordination Compounds of $\mathbf{I}$. A MeOH solution $(30-50 \mathrm{~mL})$ of the appropriate metal salt $(10 \mathrm{mmol})$ was added to a $\mathrm{MeOH}$ solution $(50 \mathrm{~mL})$ of $\mathbf{I}(3.31 \mathrm{~g}, 10 \mathrm{mmol})$ and the mixture was then refluxed for $3-4 \mathrm{~h}$. The solid products formed were suction filtered, washed with, and recrystallized from $\mathrm{MeOH}$, and were then dried as mentioned above. Yield $=50-80 \%$. 
TABLE 1: Analytical, molar conductance $\left(\Lambda_{\mathrm{M}}\right)$ and molecular weight data of I and its coordination compounds.

\begin{tabular}{|c|c|c|c|c|c|c|c|c|}
\hline \multirow{2}{*}{ Compound } & \multirow{2}{*}{ Mol. formula } & \multirow{2}{*}{$\begin{array}{c}\Lambda_{\mathrm{M}} \\
\left(\mathrm{mho} \mathrm{cm}^{2} \mathrm{~mol}^{-1}\right)\end{array}$} & \multirow{2}{*}{ Mol. wt obsd (calcd) } & \multicolumn{5}{|c|}{ Obsd (calcd)\% } \\
\hline & & & & $\mathrm{M}$ & C & $\mathrm{H}$ & $\mathrm{N}$ & S \\
\hline I & $\mathrm{C}_{16} \mathrm{H}_{13} \mathrm{NO}_{5} \mathrm{~S}$ & - & $\begin{array}{c}331^{\mathrm{a}} \\
(331.0)\end{array}$ & - & $\begin{array}{c}57.80 \\
(58.01)\end{array}$ & $\begin{array}{c}3.75 \\
(3.93)\end{array}$ & $\begin{array}{c}4.10 \\
(4.23)\end{array}$ & $\begin{array}{c}9.50 \\
(9.67)\end{array}$ \\
\hline II & $\mathrm{MnC}_{19} \mathrm{H}_{23} \mathrm{NO}_{8} \mathrm{~S}$ & 6.2 & $\begin{array}{l}453.1^{\mathrm{b}} \\
(479.9)\end{array}$ & $\begin{array}{c}11.20 \\
(11.44)\end{array}$ & $\begin{array}{c}47.30 \\
(47.51)\end{array}$ & $\begin{array}{c}4.85 \\
(4.79)\end{array}$ & $\begin{array}{c}2.70 \\
(2.92)\end{array}$ & $\begin{array}{c}6.55 \\
(6.67)\end{array}$ \\
\hline III & $\mathrm{CuC}_{17} \mathrm{H}_{15} \mathrm{NO}_{6} \mathrm{~S}$ & 9.3 & $\begin{array}{l}403.6 \\
424.5^{\mathrm{b}}\end{array}$ & $\begin{array}{c}14.70 \\
(14.96)\end{array}$ & $\begin{array}{c}48.17 \\
(48.06)\end{array}$ & $\begin{array}{c}3.57 \\
(3.53)\end{array}$ & $\begin{array}{c}3.21 \\
(3.30)\end{array}$ & $\begin{array}{c}7.69 \\
(7.54)\end{array}$ \\
\hline IV & $\mathrm{ZnC}_{17} \mathrm{H}_{15} \mathrm{NO}_{6} \mathrm{~S}$ & 8.5 & $\begin{array}{l}448.2^{\mathrm{b}} \\
(426.4)\end{array}$ & $\begin{array}{c}15.20 \\
(15.34)\end{array}$ & $\begin{array}{c}47.70 \\
(47.84)\end{array}$ & $\begin{array}{c}3.30 \\
(3.52)\end{array}$ & $\begin{array}{c}3.10 \\
(3.28)\end{array}$ & $\begin{array}{c}7.62 \\
(7.50)\end{array}$ \\
\hline $\mathbf{V}$ & $\mathrm{FeC}_{18} \mathrm{H}_{19} \mathrm{NO}_{7} \mathrm{SCl}$ & 13.8 & $\begin{array}{l}461.5^{\mathrm{b}} \\
(484.5)\end{array}$ & $\begin{array}{c}11.30 \\
(11.56)\end{array}$ & $\begin{array}{c}44.28 \\
(44.58)\end{array}$ & $\begin{array}{c}3.75 \\
(3.92)\end{array}$ & $\begin{array}{c}2.72 \\
(2.89)\end{array}$ & $\begin{array}{c}6.40 \\
(6.60)\end{array}$ \\
\hline VI & $\mathrm{MoC}_{17} \mathrm{H}_{15} \mathrm{NO}_{8} \mathrm{~S}$ & 7.1 & $\begin{array}{l}462.6^{\mathrm{b}} \\
(488.9)\end{array}$ & $\begin{array}{c}19.40 \\
(19.62)\end{array}$ & $\begin{array}{c}41.50 \\
(41.73)\end{array}$ & $\begin{array}{c}3.16 \\
(3.07)\end{array}$ & $\begin{array}{c}2.90 \\
(2.86)\end{array}$ & $\begin{array}{c}6.32 \\
(6.54)\end{array}$ \\
\hline
\end{tabular}

amass spectral data, ${ }^{\mathrm{b}}$ rast method data.

TABLE 2: IR, reflectance spectral data $\left(\mathrm{cm}^{-1}\right)$, and magnetic moments of coordination compounds of I.

\begin{tabular}{lccccccc}
\hline Compound & $v_{\mathrm{as}}(\mathrm{COO})$ & $v_{\mathrm{s}}(\mathrm{COO})$ & $v(\mathrm{C}-\mathrm{O})(\mathrm{phenolic})$ & $v(\mathrm{C}-\mathrm{S})$ & $v(\mathrm{C}-\mathrm{O})(\mathrm{MeOH})$ & $v_{\max }$ & Mag. moment (B.M.) \\
\hline I & - & & 1525 & 835 & - & - & Diamagnetic \\
II & 1560 & 1348 & 1530 & 820 & 994 & $17450,22320,25300$ & 5.90 \\
III & 1558 & 1333 & 1532 & 805 & 980 & 17230 & 2.02 \\
IV & 1565 & 1350 & 1535 & 810 & 985 & - & Diamagnetic \\
V & 1570 & 1350 & 1533 & 818 & 970 & $12700,16100,24900$ & 5.95 \\
VI & 1575 & 1360 & 1534 & 800 & 980 & - & Diamagnetic \\
\hline
\end{tabular}

\section{Results and Discussion}

A dry benzene solution of the Schiff base (obtained by the nucleophilic addition reaction between 3-aldehydo2-hydroxybenzoic acid and 2-aminopohenol followed by the elimination of one water molecule) reacts with mercaptoacetic acid and forms $N$-(2-hydroxyphenyl)C-( $3^{\prime}$-carboxy- $2^{\prime}$-hydroxyphenyl)thiazolidin-4-one, $\mathrm{LH}_{3}$ (I). The reaction of $\mathbf{I}$ with appropriate metal salt in 1:1 molar ratio in $\mathrm{MeOH}$ produces the coordination compounds, $\left[\mathrm{Mn}(\mathrm{LH})(\mathrm{MeOH})_{3}\right],\left[\mathrm{M}^{\prime}(\mathrm{LH})(\mathrm{MeOH})\right]$ [where $\left.\mathrm{M}^{\prime}=\mathrm{Cu}^{\mathrm{II}}, \mathrm{Zn}^{\mathrm{II}}, \mathrm{MoO}_{2}{ }^{\mathrm{VI}}\right]$ and $\left[\mathrm{FeCl}(\mathrm{LH})(\mathrm{MeOH})_{2}\right]$. The formations of $\mathbf{I}$ from the Schiff base and the coordination compounds of the latter take place according to the Schemes 1 and 2 .

The coordination compounds are stable at room temperature. They are insoluble in $\mathrm{H}_{2} \mathrm{O}$, partially soluble in $\mathrm{MeOH}, \mathrm{EtOH}$, and completely soluble in DMSO and DMF. Their molar conductance measurements $\left(\Lambda_{\mathrm{M}}=6.2-\right.$ $13.8 \mathrm{mho} \mathrm{cm}^{2} \mathrm{~mol}^{-1}$ ) in DMF indicate their nonelectrolytic nature. The analytical data of $\mathbf{I}$ and its coordination compounds are presented in Table 1.

3.1. Infrared Spectral Studies. The infrared spectra of the Schiff base (N-(2-hydroxyphenyl)- $3^{\prime}$-carboxy- $2^{\prime}$-hydroxy benzylideneimine), $\mathrm{LH}_{3}$ (I) (N-(2-hydroxyphenyl)-C-( $3^{\prime}$ carboxy-2' -hydroxyphenyl)thiazoli-din-4-one), and the coordination compounds of $\mathbf{I}$ were recorded in $\mathrm{KBr}$ and the prominent peaks (in $\mathrm{cm}^{-1}$ ) are shown in Table 2. The Schiff base exhibits the $v(\mathrm{C}=\mathrm{N})$ (azomethine) stretch at $1630 \mathrm{~cm}^{-1}$. This band disappears in $\mathrm{I}$ and a new band appears at $1575 \mathrm{~cm}^{-1}$ due to the $v(\mathrm{C}-\mathrm{N})$ (thiazolidinone ring) stretch [28] indicating the conversion of the Schiff base into I. The formation of $\mathbf{I}$ is further supported by the appearance of a new band at $835 \mathrm{~cm}^{-1}$ due to the $v(\mathrm{C}-\mathrm{S})$ (thiazolidinone ring) stretch [29], and it shows a negative shift by $15-35 \mathrm{~cm}^{-1}$ in the coordination compounds indicating the involvement of the $\mathrm{S}$ atom of the thiazolidinone moiety towards coordination [30]. I shows the $v(\mathrm{C}=\mathrm{O})$ (thiazolidinone ring) stretch [31] at $1700 \mathrm{~cm}^{-1}$. This band remains unchanged in the coordination compounds indicating the noninvolvement of $\mathrm{O}$ atom towards the coordination. I exhibits a strong band at $2860 \mathrm{~cm}^{-1}$ due to the intramolecular $\mathrm{H}$-bonded $[32,33] \mathrm{OH}$ group of phenolic and/or carboxylic acid moieties. This band disappears in the coordination compounds indicating the breakdown of H-bonding and subsequent deprotonation of the $\mathrm{OH}$ group followed by the involvement of phenolic and carboxylic acid $\mathrm{O}$ atoms towards coordination. The presence of a broad band at $\sim 3400 \mathrm{~cm}^{-1}$ due to $v(\mathrm{O}-\mathrm{H})(\mathrm{MeOH})$ and the decrease of $v(\mathrm{C}-\mathrm{O})(\mathrm{MeOH})$ stretch from $1034 \mathrm{~cm}^{-1}$ to lower energy by $40-64 \mathrm{~cm}^{-1}$ in the coordination compounds of I indicate the involvement of the $\mathrm{O}$ atom of $\mathrm{MeOH}$ towards coordination [34]. The appearance of two new bands between $1558-1575 \mathrm{~cm}^{-1}, v_{\text {as }}(\mathrm{COO})$ and $1333-1360 \mathrm{~cm}^{-1}, v_{\mathrm{s}}(\mathrm{COO})$ stretches indicate the presence of the coordinated carboxylate group in the coordination compounds. The energy difference 


$$
\text { Schiff base } \stackrel{\mathrm{HS}-\mathrm{CH}_{2} \mathrm{COOH}}{\text { Dry benzene }} \mathbf{I}
$$

Scheme 1: Preparative scheme of $\mathrm{LH}_{3}$ (I).

$$
\begin{gathered}
\mathrm{LH}_{3}+\mathrm{Mn}\left(\mathrm{CH}_{3} \mathrm{COO}\right)_{2} \cdot 4 \mathrm{H}_{2} \mathrm{O} \underset{\mathrm{Refux}}{\stackrel{\mathrm{MeOH}}{\longrightarrow}}\left[\mathrm{Mn}(\mathrm{LH})(\mathrm{MeOH})_{3}\right]+2 \mathrm{CH}_{3} \mathrm{COOH}+4 \mathrm{H}_{2} \mathrm{O} \\
\mathrm{LH}_{3}+\mathrm{M}^{\prime}\left(\mathrm{CH}_{3} \mathrm{COO}\right)_{2} \cdot y \mathrm{H}_{2} \mathrm{O} \underset{\mathrm{MeOH}}{\stackrel{\mathrm{Refux}}{\longrightarrow}}\left[\mathrm{M}^{\prime}(\mathrm{LH})(\mathrm{MeOH})_{3}\right]+2 \mathrm{CH}_{3} \mathrm{COOH}+y \mathrm{H}_{2} \mathrm{O} \\
\qquad\left[\mathrm{M}^{\prime}=\mathrm{Cu}^{\mathrm{II}}, \mathrm{Zn}^{\mathrm{II}}, \mathrm{MoO}_{2}^{\mathrm{VI}}\right] \\
\mathrm{LH}_{3}+\mathrm{FeCl}_{3} \underset{\mathrm{Refux}}{\stackrel{\mathrm{MeOH}}{\longrightarrow}}\left[\mathrm{FeCl}(\mathrm{LH})(\mathrm{MeOH})_{2}\right]+2 \mathrm{HCl}
\end{gathered}
$$

Scheme 2: Preparative scheme of coordination compounds of $\mathrm{LH}_{3}$ (I).

$\left(\Delta v=212-225 \mathrm{~cm}^{-1}\right)$ between these stretches is $>210 \mathrm{~cm}^{-1}$ which indicates the monodentate nature of the carboxylate moiety [35]. The $v(\mathrm{C}-\mathrm{O}) \phi$ stretch [34] of I occurs at $1525 \mathrm{~cm}^{-1}$. This band shifts to higher energy by $5-10 \mathrm{~cm}^{-1}$ in the coordination compounds indicating the involvement of phenolic $\mathrm{O}$ atom of either 3-aldehydo-2-hydroxybenzoic acid or 2-aminopohenol moieties towards coordination. On the basis of steric grounds, we suggest the noninvolvement of phenolic (2-aminophenol moiety) $\mathrm{O}$ atom towards coordination. The absence of a band between $820-860 \mathrm{~cm}^{-1}$ in $\mathbf{V}$ precludes the presence of the $(\mathrm{Fe}-\mathrm{O}-\mathrm{Fe})$ bridged structure [36]. The presence of a peak at $357 \mathrm{~cm}^{-1}$ in $\mathbf{V}$ confirms the presence of $\mathrm{Fe}-\mathrm{Cl}$ linkage [37] in the compound. VI exhibits the $v_{\mathrm{s}}(\mathrm{O}=\mathrm{Mo}=\mathrm{O})$ and $v_{\mathrm{as}}(\mathrm{O}=\mathrm{Mo}=\mathrm{O})$ stretches at 946 and $910 \mathrm{~cm}^{-1}$, respectively [38]. These bands occur in the usual ranges: $v_{\mathrm{s}}(\mathrm{O}=\mathrm{Mo}=\mathrm{O})$ stretch, $892-964 \mathrm{~cm}^{-1}$ and $v_{\mathrm{as}}(\mathrm{O}=\mathrm{Mo}=\mathrm{O})$ stretch, $842-928 \mathrm{~cm}^{-1}$, reported for the majority of $\mathrm{MoO}_{2}{ }^{\mathrm{VI}}$ compounds [38]. The presence of two bands due to the $v(\mathrm{O}=\mathrm{Mo}=\mathrm{O})$ stretch is indicative of a cis- $\mathrm{MoO}_{2}$ configuration as the compound with trans $-\mathrm{MoO}_{2}$ structure shows only $v_{\text {as }}(\mathrm{O}=\mathrm{Mo}=\mathrm{O})$ stretch since the $v_{\mathrm{s}}(\mathrm{O}=\mathrm{Mo}=\mathrm{O})$ stretch is IR inactive [39]. The absence of a band at $\sim 775 \mathrm{~cm}^{-1}$ in the $\mathrm{MoO}_{2}{ }^{\mathrm{VI}}$ compound indicates the absence of an oligomeric chain with $\cdots$ Mo $\cdots$ Mo $\cdots$ Mo $\cdots$ interaction [40]. The new nonligand bands in the present coordination compounds in the low frequency region are assigned to the $v(\mathrm{M}-\mathrm{O})\left(550-570 \mathrm{~cm}^{-1}\right)$ and the $v(\mathrm{M}-\mathrm{S})\left(345-370 \mathrm{~cm}^{-1}\right)$ and these bands [41] are in the expected order of increasing energy: $v(\mathrm{M}-\mathrm{S})$ $<v(\mathrm{M}-\mathrm{O})$. On the basis of analytical data (Table 1), valence requirements, and the infrared spectral studies, it is proposed that $\mathbf{I}$ behaves as a dibasic tridentate OOS donor ligand in the coordination compounds.

3.2. Reflectance Spectral Studies. II exhibits three bands at 17450, 22320, and $25300 \mathrm{~cm}^{-1}$ due to ${ }^{6} A_{1 \mathrm{~g}} \rightarrow{ }^{4} T_{1 \mathrm{~g}}(G)$, ${ }^{6} A_{1 \mathrm{~g}} \rightarrow{ }^{4} T_{2 \mathrm{~g}}(G)$, and ${ }^{6} A_{1 \mathrm{~g}} \rightarrow{ }^{4} A_{1 \mathrm{~g}}(G)$ transitions, respectively, in an octahedral environment [42]. The presence of an asymmetric broad band at $17230 \mathrm{~cm}^{-1}$ due to the ${ }^{2} B_{1 \mathrm{~g}} \rightarrow$ ${ }^{2} A_{1 \mathrm{~g}},{ }^{2} B_{2 \mathrm{~g}}$, and ${ }^{2} E_{\mathrm{g}}$ transitions in III suggests a square-planar arrangement of $\mathbf{I}$ around $\mathrm{Cu}^{\mathrm{II}}$ ion [43]. The absence of a band in the range $8000-10000 \mathrm{~cm}^{-1}$ precludes the presence of a tetrahedral structure [44]. V exhibits three bands at 12700, 16100 , and $24900 \mathrm{~cm}^{-1}$ due to ${ }^{6} A_{1 \mathrm{~g}} \rightarrow{ }^{4} T_{1 \mathrm{~g}}(G),{ }^{6} A_{1 \mathrm{~g}} \rightarrow$ ${ }^{4} T_{2 \mathrm{~g}}(G)$, and ${ }^{6} A_{1 \mathrm{~g}} \rightarrow{ }^{4} A_{1 \mathrm{~g}}(G)$ transitions, respectively, in an octahedral environment [45].

3.3. Magnetic Measurements. The room temperature magnetic moments of the coordination compounds of $\mathbf{I}$ are presented in Table 2. The magnetic moments of II, III, and V are 5.90, 2.02, and 5.95 B.M., respectively. These values are indicative of magnetically dilute high-spin octahedral coordination compounds of $\mathrm{Mn}^{\mathrm{II}}$ and $\mathrm{Fe}^{\mathrm{III}}$ ions [46]. The IV and VI are diamagnetic as expected.

3.4. ESR Studies. The ESR spectra of III shows well resolved four hyperfine lines with no super hyperfine lines. The various ESR spectral parameters obtained are as follows: $g_{\|}=$ 2.26, $g_{\perp}=2.09, A_{\|}=1.916 \times 10^{-2} \mathrm{~cm}^{-1}, A_{\perp}=0.467 \times$ $10^{-2} \mathrm{~cm}^{-1}, G=2.93, \alpha_{\mathrm{Cu}}^{2}=0.87,\left(\alpha^{\prime}\right)^{2}=0.19, \kappa=0.55$, and $P_{d}=1.86 \times 10^{-2} \mathrm{~cm}^{-1}$. The observed order of $A$ and $g$ values $\left(A_{\|}>A_{\perp} ; g_{\|}>g_{\perp}>2.0023\right)$ indicate that the complex possesses a square planar structure [47] and the ground state $[48,49]$ of $\mathrm{Cu}(\mathrm{II})$ is predominantly $d_{x^{2}-y^{2}}$ $\left({ }^{2} \mathrm{~B}_{1}\right.$ as the ground state). Here $g_{\|}$and $g_{\perp}$ values denote the effective g-values when the externally applied DC field is parallel $\left(B_{\|}\right)$and perpendicular $\left(B_{\perp}\right)$ to the symmetry axis of the crystalline field around the paramagnetic centre, respectively. The value of geometric parameter $(G)$, a measure of the exchange interaction, is 2.93, and this value lies within the range [50] 2.1-3.8, consistent with the ground state [47] $d_{x^{2}-y^{2}}$. Further the value of $g_{\|} / A_{\|}$for the complex is $117.95 \mathrm{~cm}$ which lies in the range $(90-140) \mathrm{cm}$ as reported for square planar $\mathrm{Cu}$ (II) complexes [26]. For ionic environments, $g_{\|}$is normally $\geq 2.3$ and is $<2.3$ for covalent environments. 


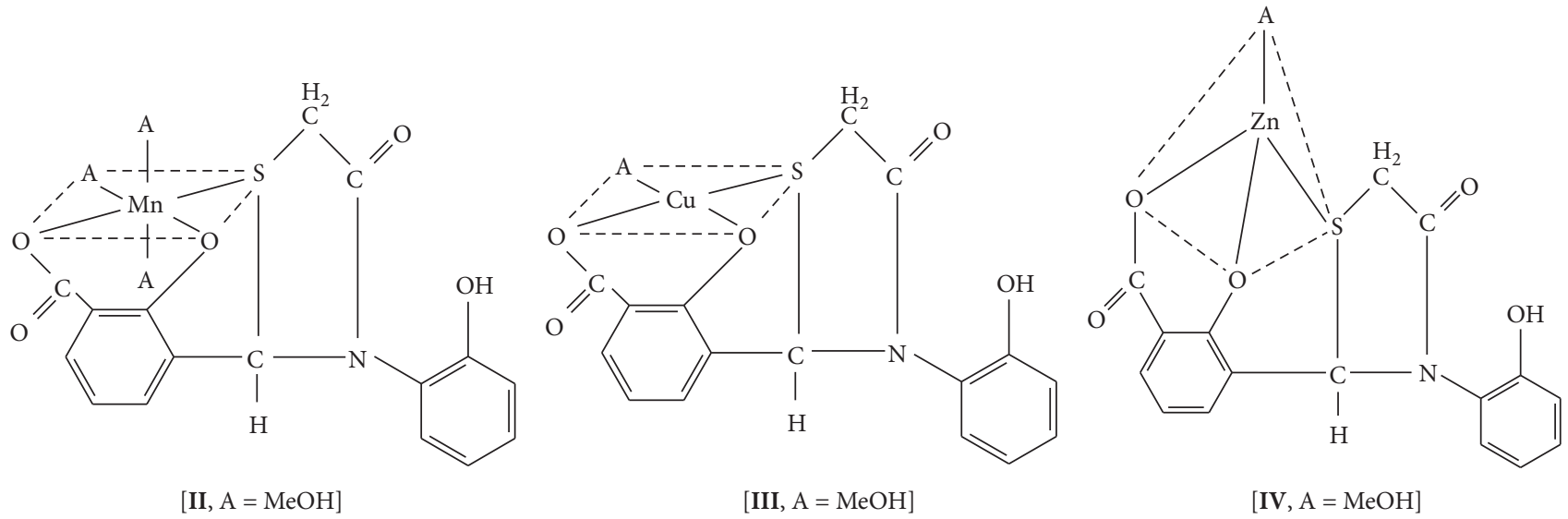

(a)

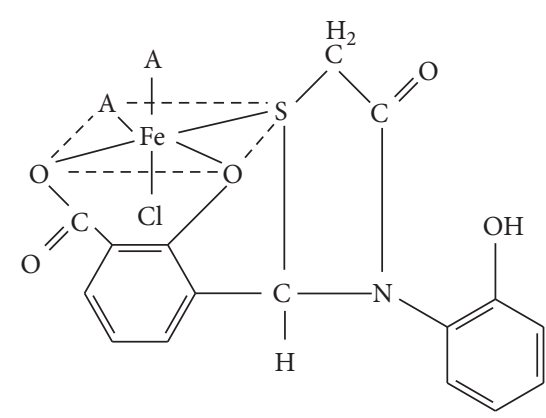

$[\mathbf{V}, \mathrm{A}=\mathrm{MeOH}]$

(d) (b)

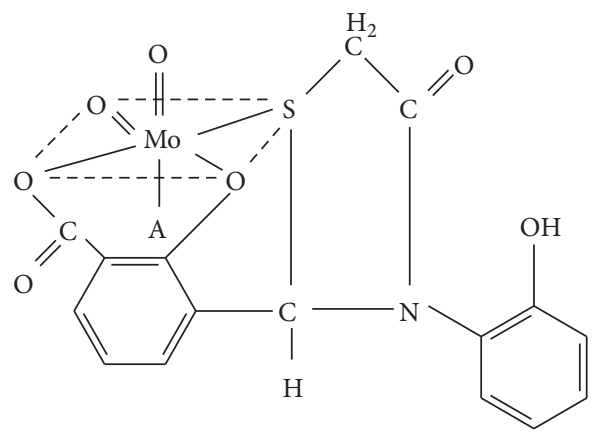

[VI, $\mathrm{A}=\mathrm{MeOH}]$

(e)

Figure 2

The $g_{\|}$value (2.26) indicates that the metal-ligand bonding in the compound is covalent. The $G$ value (2.93) is less than 4.0 , hence the ligand forming the $\mathrm{Cu}^{\mathrm{II}}$ compound is regarded as a strong field ligand. The in-plane covalence parameter $\left(\alpha_{\mathrm{Cu}}^{2}\right)$ has been calculated using the relation: $\alpha_{\mathrm{Cu}}^{2}=\left(g_{\|^{-}}\right.$ $2.002)+3 / 7\left(g_{\perp}-2.002\right)-\left(A_{\|} / 0.036\right)+0.04$, where $\alpha$ is related to the overlap integral $(S)$ according to the relation [51]: $\alpha^{2}-2 \alpha \alpha^{\prime} S+\left(\alpha^{\prime}\right)^{2}=1$. The values of $\alpha_{\mathrm{Cu}}^{2}(0.87)$ and $\left(\alpha^{\prime}\right)^{2}$ (0.19) indicate its covalent nature. The smaller the value of $\alpha_{\mathrm{Cu}}^{2}$, the more covalent is the bonding; $\alpha_{\mathrm{Cu}}^{2}=1$ indicates completely ionic bonding, while $\alpha_{\mathrm{Cu}}^{2}=0.5$ indicates completely covalent bonding [26]. The larger the value of $\left(\alpha^{\prime}\right)^{2}$, the more covalent is the bonding; $\left(\alpha^{\prime}\right)^{2}=0$ suggests a complete ionic bonding [26]. The symbol $\kappa P_{d}$ represents the Fermi contact contribution $(A)$ to the coupling, where $P_{d}$ is the dipolar contribution. The value of $P_{d}$ and $\kappa$ have been calculated using the relation $[48,49]: P_{d}=-\left(A_{\|}-A_{\perp}\right) / 0.78$ and $\kappa=-0.48-\left(A_{\|} / P_{d}\right)$. The positive value of $\kappa$ suggests that $A_{\|}$should be greater than $A_{\perp}$ and it has also been observed by us. The lower value of $P_{d}$ in comparison to that of the free ion value $\left(3.5 \times 10^{-2} \mathrm{~cm}^{-1}\right)$ indicates the presence of covalent character between the metal-ligand bonding. The absence of any band $\sim 1500 \mathrm{G}$ due to the $\Delta M s= \pm 2$ transition rules out the presence of $\mathrm{M}-\mathrm{M}$ interaction.

\section{Conclusion}

Thus, on the basis of analytical, molecular weight, spectral, and magnetic studies, we suggest a square-planar structure, III for $[\mathrm{Cu}(\mathrm{LH})(\mathrm{MeOH})]$, a tetrahedral structure, IV for $[\mathrm{Zn}(\mathrm{LH})(\mathrm{MeOH})]$ and an octahedral structure, II for $\left[\mathrm{Mn}(\mathrm{LH})(\mathrm{MeOH})_{3}\right], \mathbf{V}$ for $\left[\mathrm{FeCl}(\mathrm{LH})(\mathrm{MeOH})_{2}\right]$, and VI for $\left[\mathrm{MoO}_{2}(\mathrm{LH})(\mathrm{MeOH})\right]$ as shown in Figure 2.

\section{References}

[1] B. Singh, A. Maheshwari, G. Dak, K. Sharma, and G. L. Talesara, "Studies of antimicrobial activities of some 4-thiazolidinone fused pyrimidines, [1,5]-benzodiazepines and their oxygen substituted hydroxylamine derivatives," Indian Journal of Pharmaceutical Sciences, vol. 72, no. 5, pp. 607-612, 2010.

[2] S. M. Kudari and S. E. Badiger, "Synthesis of new series of 1,8bis (2-arylimino thiazolidin-4-one-3-yl) octanes and related 
octanes," Indian Journal of Heterocyclic Chemistry, vol. 9, no. 2, pp. 95-98, 1999.

[3] M. Pulici and F. Quartieri, "Traceless solid-phase synthesis of 2-amino-5-alkylidene-thiazol-4-ones," Tetrahedron Letters, vol. 46, no. 14, pp. 2387-2391, 2005.

[4] F. C. Brown, "4-Thiazolidinones," Chemical Reviews, vol. 61, no. 5, pp. 463-521, 1961.

[5] G. C. Look, J. R. Schullek, C. P. Holmes, J. P. Chinn, E. M. Gordon, and M. A. Gallop, "The identification of cyclooxygenase1 inhibitors from 4-thiazolidinone combinatorial libraries," Bioorganic and Medicinal Chemistry Letters, vol. 6, no. 6, pp. 707-712, 1996.

[6] C. J. Andres, J. J. Bronson, S. V. D’Andrea et al., “4Thiazolidinones: novel inhibitors of the bacterial enzyme MurB," Bioorganic and Medicinal Chemistry Letters, vol. 10, no. 8, pp. 715-717, 2000.

[7] M. L. Barreca, A. Chimirri, L. De Luca et al., "Discovery of 2,3-diaryl-1,3-thiazolidin-4-ones as potent anti-HIV-1 agents," Bioorganic and Medicinal Chemistry Letters, vol. 11, no. 13, pp. 1793-1796, 2001.

[8] M. V. Diurno, O. Mazzoni, E. Piscopo, A. Calignano, F. Giordano, and A. Bolognese, "Synthesis and antihistaminic activity of some thiazolidin-4-ones," Journal of Medicinal Chemistry, vol. 35, no. 15, pp. 2910-2912, 1992.

[9] V. V. Mulwad and B. P. Choudhari, "Synthesis and antimicrobial screening of $\mathrm{N}$ [coumarin-6-ylamino] thiazolidinone and spiroindolthiazoli-dinone derivatives," Indian Journal of Chemistry B, vol. 44, p. 1074, 2005.

[10] N. J. Gaikwad and S. B. Agrawal, "Substituted 4-Thiazolidinones as Anticonulsants VII," Indian Drugs, vol. 34, pp. 542-543, 1997.

[11] T. Kato, T. Ozaki, K. Tamura, Y. Suzuki, M. Akima, and N. Ohi, "Novel calcium antagonists with both calcium overload inhibition and antioxidant activity. 2. Structure-activity relationships of thiazolidinone derivatives," Journal of Medicinal Chemistry, vol. 42, no. 16, pp. 3134-3146, 1999.

[12] R. P. Pawar, N. M. Andurkar, S. R. Bhusare, and Y. B. Vibhute, "Synthesis and antibacterial activity of some new simple and heterocyclic Schiff bases," Oriental Journal of Chemistry, vol. 15, no. 1, pp. 157-160, 1999.

[13] D. A. Vyas, N. A. Chauhan, and A. R. Parikh, "Synthesis and microbial activity of quinoxaline based thiazidinones and azetidinone," Indian Journal of Chemistry B, vol. 46, pp. 1699-1702, 2007.

[14] S. B. Junne, S. S. Wadje, M. M. V. Baig, and Y. B. Vibhute, "Novel heterocyclic Schiff bases, 4-Thiazolidinones and 2Azetidinones possessing antibacterial and antifungal activity," International Journal of Chemical Sciences, vol. 5, p. 2093, 2007.

[15] A. M. Rehab, A. Hasani, M. M. Sinan, A. Byatti, M. S. Sarab, and M. S. Al Azawi, "Synthesis, Structural and Biological Studies of /3-(1, 3- benzothiazol-2-yl) - /4H- spiro[indole2,3[1,3]thiazolidine]- 2,/4(1H) dion with Cr (III), Mn (II), Co (II), $\mathrm{Ni}$ (II), Cu (II), and Zn (II) ions," Engineering \& Technology Journal, vol. 29, no. 15, pp. 3067-3078.

[16] M. F. El-Sherbiny, "Potentiometric and thermodynamic studies of 2-thioxothiazolidin-4-one and its metal complexes," Chemical Papers, vol. 59, no. 5, pp. 332-335, 2005.

[17] E. Subasi, A. Ercag, S. Sert, and O. S. Senturk, "Photochemical complexation reactions of $\mathrm{M}(\mathrm{CO})_{6}(\mathrm{M}=\mathrm{Cr}, \mathrm{Mo}, \mathrm{W})$ and $\operatorname{Re}(\mathrm{CO})_{6} \mathrm{Br}$ with Rhodanine (4-Thiazolidinone-2-thioxo) and 5-Substituted Rhodanines," Synthesis and Reactivity in Inorganic and Metal-Organic Chemistry and Nano-Metal Chemistry, vol. 36, pp. 705-711, 2006.
[18] L.-J. Ming, "Structure and function of 'Metalloantibiotics," Medicinal Research Reviews, vol. 23, no. 6, pp. 697-762, 2003.

[19] J. R. Anacona and I. Rodriguez, "Synthesis and antibacterial activity of cephalexin metal complexes," Journal of Coordination Chemistry, vol. 57, no. 15, pp. 1263-1269, 2004.

[20] Z. H. Chohan, H. Pervez, K. M. Khan, A. Rauf, and C. T. Supuran, "Binding of transition metal ions [cobalt, copper, nickel and zinc] with furanyl-, thiophenyl-, pyrrolyl-, salicylyland pyridyl-derived cephalexins as potent antibacterial agents," Journal of Enzyme Inhibition and Medicinal Chemistry, vol. 19, no. 1, pp. 51-56, 2004.

[21] J. R. Anacona and J. Estacio, "Synthesis and antibacterial activity of cefixime metal complexes," Transition Metal Chemistry, vol. 31, no. 2, pp. 227-231, 2006.

[22] D. H. Brown, W. E. Smith, J. W. Teape, and A. J. Lewis, "Antiinflammatory effects of some copper complexes," Journal of Medicinal Chemistry, vol. 23, no. 7, pp. 729-734, 1980.

[23] Y. Nishida, I. Watanabe, and K. Unoura, "Model compounds for Fe- or Mn-containing SOD and their SOD-like function," Chemistry Letters, vol. 20, no. 9, pp. 1517-1520, 1991.

[24] D. Kumar, A. Syamal, A. Kumar, P. K. Gupta, and D. Dass, "Syntheses and characterization of coordination compounds of $\mathrm{N}$-(2-mercaptoethyl)-4-( $3^{\prime}$-carboxy-2' -hydroxyphenyl)-2azetidinone," Journal of the Indian Chemical Society, vol. 87, no. 4, pp. 417-423, 2010.

[25] F. G. Mann and B. C. Saunders, Practical Organic Chemistry, Longmans, London, UK, 1961.

[26] R. L. Dutta and A. Syamal, Elements of Magnetochemistry, Affiliated East West Press, New Delhi, India, 2nd edition, 1993.

[27] A. Syamal and M. M. Singh, "Synthesis and characterization of new polymer supported chelating resins," Journal of Polymer Materials, vol. 6, pp. 175-179, 1989.

[28] A. Yamaguchi, R. B. Penland, S. Mizushima, T. J. Lane, C. Curran, and J. V. Quagliano, "Infrared absorption spectra of inorganic coordination complexes. XIV. Infrared studies of some metal thiourea complexes," Journal of the American Chemical Society, vol. 80, no. 3, pp. 527-529, 1958.

[29] M. J. Campbell and R. Grzeskowiak, "Some copper(II) complexes of thiosemicarbazide," Journal of the Chemical Society A, pp. 396-401, 1967.

[30] R. K. Patel, "Synthesis and characterization of some metal complexes of $\mathrm{Co}(\mathrm{II}), \mathrm{Ni}(\mathrm{II})$ and $\mathrm{Cu}(\mathrm{II})$ with 2-benzoylhydrazono-4thiazolidinone," Asian Journal of Chemistry, vol. 13, no. 1, pp. 89-92, 2001.

[31] P. V. Patel and K. R. Desai, "Synthesis of 2-methyl-5-nitro-n-4'(4-aryl-1'"',5"'-benzothiazepines)-phenylbenzenesulfonamide by the reaction of 2-methyl-5-nitrobenzensulfonamide chalcones with 2-aminothiophenol," Oriental Journal of Chemistry, vol. 18, no. 2, p. 311, 2002.

[32] P. J. Bahad, N. S. Bhave, and A. S. Aswar, Journal of the Indian Chemical Society, vol. 77, p. 363, 2000.

[33] A. Syamal and D. Kumar, "New Zirconium (IV) complexes with the ons donor triden tate schiff bases derived from salicyaldehyde or substituted salicylal dehydes and 2-aminobih anethiol," Synthesis and Reactivity in Inorganic and MetalOrganic Chemistry, vol. 14, no. 3, pp. 325-337, 1984.

[34] A. Syamal and D. Kumar, "Syntheses of new zirconium (IV) complexes with the tridentate Schiff bases derived from o-aminophenol and salicylaldehydes or 2-hydroxy-1naphthaldehyde," Indian Journal of Chemistry A, vol. 24, p. 62, 1985. 
[35] D. Kumar and A. Kumar, "Syntheses, magnetic and spectral studies on the coordination compounds of the polystyreneanchored thiazolidin-4-one," E-Journal of Chemistry, vol. 9, no. 4, pp. 2532-2539, 2012.

[36] D. Kumar, P. K. Gupta, A. Kumar, D. Dass, and A. Syamal, "Syntheses, spectroscopic, and magnetic properties of polystyreneanchored coordination compounds of tridentate ONO donor Schiff base," Journal of Coordination Chemistry, vol. 64, no. 4, pp. 590-599, 2011.

[37] A. Choudhary, R. Sharma, M. Nagar, M. Mohsin, and H. S. Meena, "Synthesis, characterization and antioxidant activity of some transition metal complexes with terpenoid derivatives," Journal of the Chilean Chemical Society, vol. 56, pp. 911-917, 2011.

[38] D. Kumar, A. Syamal, and L. K. Sharma, "Synthesis and characterization of polystyrene-anchored monobasic bidentate Schiff base and its complexes with bi-, tri-, tetra- and hexavalent metal ions," Journal of Coordination Chemistry, vol. 61, no. 11, pp. 1788-1796, 2008.

[39] A. Syamal and M. R. Maurya, "Dioxomolybdenum(VI) complexes with tridentate dibasic Schiff bases derived from various hydrazides," Transition Metal Chemistry, vol. 11, no. 6, pp. 235-238, 1986.

[40] A. Syamal, M. M. Singh, and D. Kumar, "Syntheses and characterization of a chelating resin containing ONNO donor quadridentate Schiff base and its coordination complexes with copper(II), nickel(II), cobalt(II), iron(III), zinc(II), cadmium(II), molybdenum(VI) and uranium(VI)," Reactive and Functional Polymers, vol. 39, no. 1, pp. 27-35, 1999.

[41] M. R. Chaurasia, " $\mathrm{Cu}(\mathrm{II}), \mathrm{Ni}(\mathrm{II})$ and $\mathrm{Co}(\mathrm{II})$ complexes of $\mathrm{N}-$ phenyl-benzothiazolyl thiocarbamide," Journal of Inorganic and Nuclear Chemistry, vol. 37, no. 6, pp. 1547-1548, 1975.

[42] A. B. P. Lever, Inorganic Electronic Spectroscopy, Elsevier, Amsterdam, The Netherlands, 2nd edition, 1984.

[43] S. G. Shirodkar, P. S. Mane, and T. K. Chondhekar, "Synthesis and fungitoxic studies of $\mathrm{Mn}(\mathrm{II}), \mathrm{Co}(\mathrm{II}), \mathrm{Ni}(\mathrm{II})$ and $\mathrm{Cu}(\mathrm{II})$ with some heterocyclic schiff base ligands," Indian Journal of Chemistry A, vol. 40, no. 10, pp. 1114-1117, 2001.

[44] B. B. Mahapatra and P. Ray, "Polymetallic complexes. PartLXXVII. complexes of $\mathrm{Mn}^{\mathrm{II}}, \mathrm{Co}^{\mathrm{II}}, \mathrm{Ni}^{\mathrm{II}}, \mathrm{Cu}^{\mathrm{II}}, \mathrm{Zn}^{\mathrm{II}}, \mathrm{Cd}^{\mathrm{II}}$ and $\mathrm{Hg}^{\mathrm{II}}$ with NOON and ONOONO Donor Azodye Ligands," Journal of the Indian Chemical Society, vol. 79, pp. 609-610, 2002.

[45] D. Kumar, A. Syamal, and A. K. Singh, "Synthesis and characterization of manganese(II), cobalt(II), nickel(II), copper(II), zinc(II), cadmium(II), iron(III), zirconium(IV), dioxo- molybdenum(VI) and dioxouranium(VI) coordination compounds of polystyrene-supported tridentate dibasic Schiff base derived from semicarbazide and 3- formylsalicylic acid," Indian Journal of Chemistry A, vol. 42, p. 280, 2003.

[46] F. A. Cotton, G. Wilkinson, C. A. Murillo, and M. Bochmann, Advanced Inorganic Chemistry, John Wiley, New York, NY, USA, 6th edition, 1999.

[47] D. Kumar, A. Syamal, A. Gupta, M. Rani, and P. K. Gupta, "Role of $\mathrm{pH}$ on the formation of the coordination compounds with the Schiff base derived from 3-formylsalicylic acid and 4-amino-2,3-dimethyl-1-phenyl-3- pyrazolin-5-one," Journal of the Indian Chemical Society, vol. 87, no. 10, pp. 1185-1197, 2010.

[48] A. Syamal, D. Kumar, A. K. Singh, P. K. Gupta, Jaipal, and L. K. Sharma, "Synthesis and characterization of a chelating resin containing ONO donor tridentate Schiff base and its coordination compounds with copper(II), nickel(II), cobalt(II), iron(III), zinc(II), cadmium(II), manganese(II), molybdenum(VI), zirconium(IV) and uranium(VI)," vol. 41, pp. 1385-1390, 2002.

[49] Z. Shirin and R. N. Mukherjee, "Synthesis, spectra and electrochemistry of ruthenium(III) complexes with cage-like Schiffbase ligands," Polyhedron, vol. 11, no. 20, pp. 2625-2630, 1992.

[50] U. L. Kala, S. Suma, M. R. P. Kurup, S. Krishnan, and R. P. John, "Synthesis, spectral characterization and crystal structure of copper(II) complexes of 2-hydroxyacetophenone-N(4)-phenyl semicarbazone," Polyhedron, vol. 26, no. 7, pp. 1427-1435, 2007.

[51] D. Kivelson and R. Neiman, "ESR line shapes in glasses of copper complexes," The Journal of Chemical Physics, vol. 35, no. 1, pp. 149-155, 1961. 

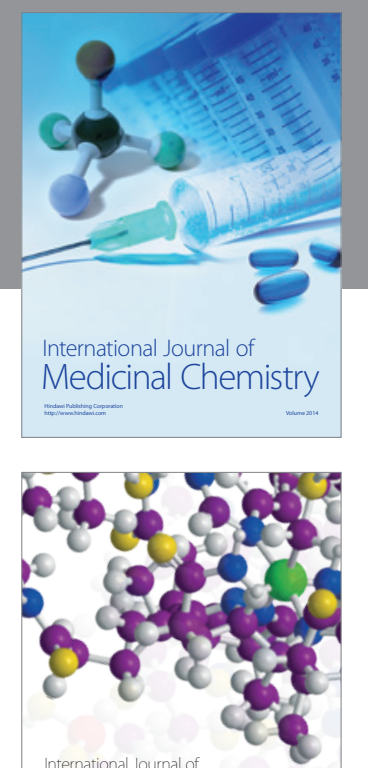

\section{Carbohydrate} Chemistry

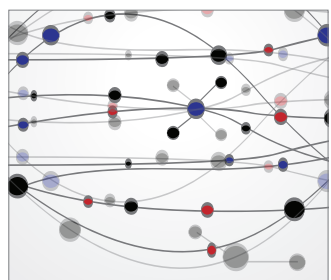

The Scientific World Journal
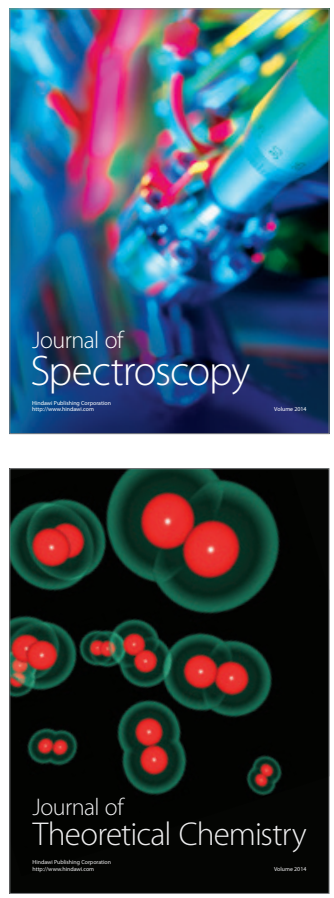
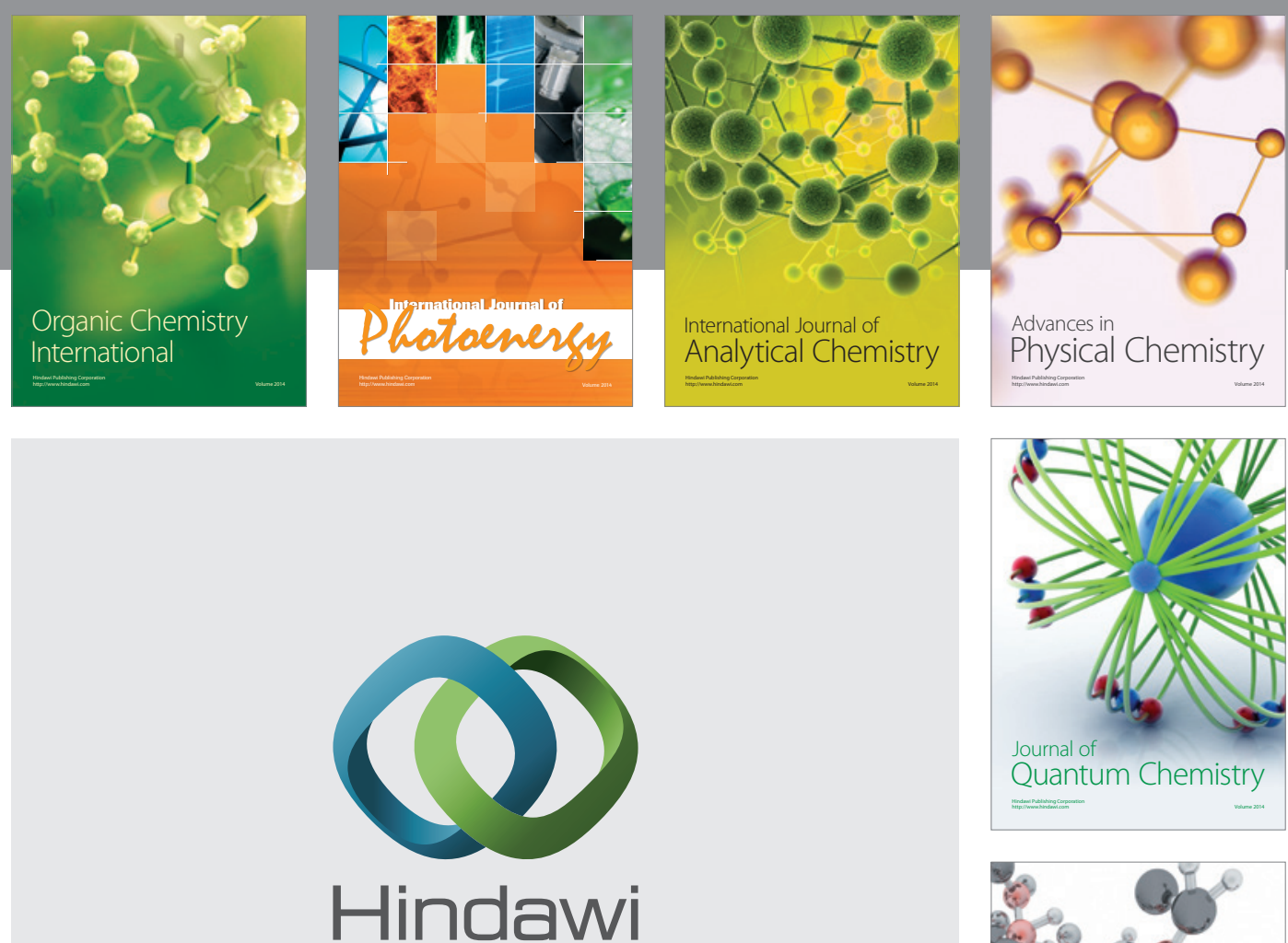

Submit your manuscripts at

http://www.hindawi.com

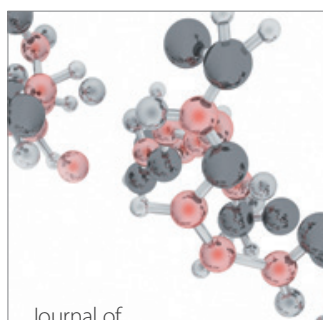

Analytical Methods

in Chemistry

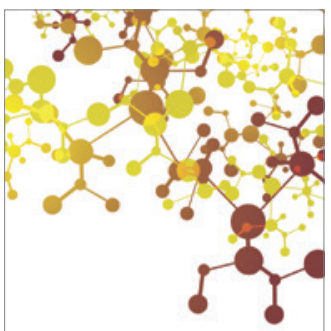

Journal of

Applied Chemistry

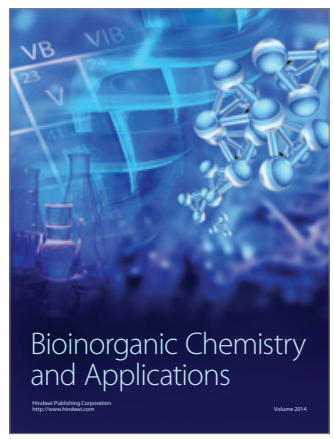

Inorganic Chemistry
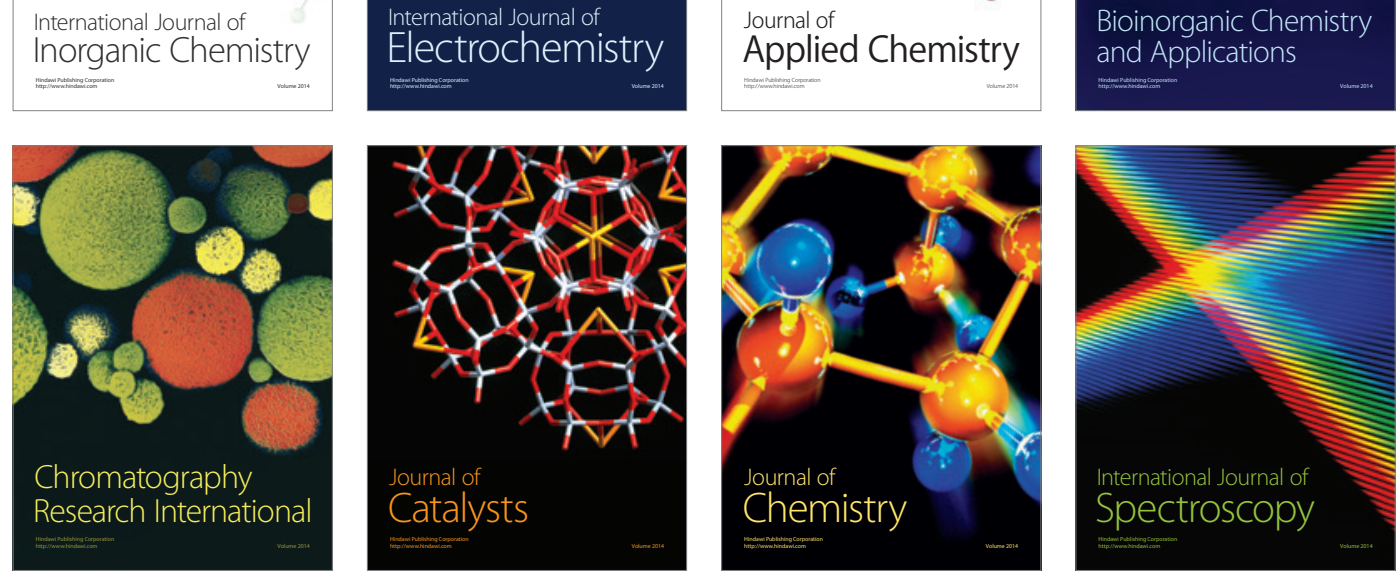